\title{
New Coumarinic Azo-Derivatives of Metoclopramide and Diphenhydramine: Synthesis and In Vitro Testing for Cholinesterase Inhibitory Effect and Protection Ability Against Chlorpyrifos.
}

\author{
Mahmood AAJa, Mustafa YS ${ }^{\mathrm{b}}$, Abdulstaar $\mathrm{Mc}^{\mathrm{c}}$ \\ aDepartment of Clinical Pharmacy, College of Pharmacy, University of Mosul, Mosul, Iraq. \\ b,c Department of Pharmaceutical Chemistry, College of Pharmacy, University of Mosul, Mosul, Iraq.
}

\begin{abstract}
Introduction: This study aims to synthesize new coumarin azo compounds of metoclopramide and diphenhydramine and to evaluate their in vitro cholinesterase inhibitory effects and protection abilities against chlorpyrifos. Methods: Two series of azo coumarin compounds were synthesized. Series I compound resulted from the diazotization of metoclopramide and then coupling with coumarin and 4-methyl coumarin to give compounds 1 and 2 respectively. Series II compound resulted from the diazotization of 7 -aminocoumarin and 7-amino 4-methyl coumarin and then coupling with diphenhydramine to give compounds 3 and 4 respectively. The new compounds were tested for their in vitro cholinesterase inhibitory effect and protection ability against chlorpyrifos using the modified Elman electrometric method. Results: Metoclopramide derivatives with coumarin show selectivity protection for ChE against chlorpyriphos inhibitory effect as protect BChE and increase the inhibition of the $\mathrm{AChE}$, or the opposite. Conclusion: Diphenhydramine derivatives with coumarin show more protective ability for both $\mathrm{BChE}$ and $\mathrm{AChE}$ as one of them shows the maximum protection for all concentration. However, the other derivative shows different manner as the low concentrations act as metoclopramide derivatives while the high concentration act as first diphenhydramine derivative (protect both $\mathrm{AChE}$ and $\mathrm{BChE}$ ).
\end{abstract}

KEYWORDS: Coumarinic azo-derivatives, metoclopramide, diphenhydramine, cholinesterase, chlorpyrifos.

\section{INTRODUCTION}

Cholinesterases (ChE) are a family of enzymes that catalyze the hydrolysis of the neurotransmitter acetylcholine into choline and acetic acid, a reaction necessary to allow a cholinergic neuron to return to its resting state after activation. ${ }^{1}$ This family involves two types; ;acetylcholinesterase (EC 3.1.1.7) (AChE), also known as true or RBC cholinesterase, found primarily in the erythrocytes and neural synapses and pseudocholinesterase (EC 3.1.1.8)(BChE), also known as plasma cholinesterase or butyrylcholinesterase, found primarily in the plasma and the liver. ${ }^{2}$

Metoclopramide (methoxychloroprocainamide) (MCP) is a dopamine D2-receptor antagonist and is a benzamide derivative with an agonistic effect at serotonin receptors (5-HT4). Clinically; MCP is used owing to its prokinetic and antiemetic effects. ${ }^{3}$ These

Corresponding author:

Ahmed A.J. Mahmood

Department of Clinical Pharmacy,

College of Pharmacy,

University of Mosul, Mosul, Iraq.

Email Ahmedsot@gmail.com

Tel. 009647701678433 effects of MCP may be enhanced due to inhibition of the cholinesterase.4,5 The drug is weakly inhibited cholinesterase activity both in vivo and in vitro ${ }^{6}$ and is reported to prevent in vitro organophosphorous compounds (OP) poisoning in $\operatorname{man}^{7}$ and in animals both in vitro and in vivo. ${ }^{8}$ The protective action of metoclopramide is thought to be a competition for the active site of enzyme with the more potent OP, thus metoclopramide may reduce the toxicity of different OP compounds as dichlorvos and daizinon. ${ }^{9}$

Diphenhydramine, an ethanolamine derivative, is a nonselective histamine $H_{1}$-receptor antagonist, mainly used for allergy symptoms caused by histamine release (anaphylaxis, rhinitis and dermatoses), also can be used for nausea and vertigo and motion sickness. ${ }^{10,11,12}$ The efficacy of diphenhydramine in the prevention and treatment of methomyl-induced toxicosis was evaluated in female rats. The results suggest that diphenhydramine could be of therapeutic value in reducing the toxic effects of methomyl. ${ }^{13,14}$ Diphenhydramine inhibits in vitro human $\mathrm{ChE}^{15}$ and in vivo in experimental animals like mice and horse..$^{13,14,16}$

Coumarin is a phytochemical (benzopyrone); a toxin found in many plants, having vanilla like flavor. It has a sweet scent and has been used in perfumes since 1882, and it used for centuries in traditional medicine. ${ }^{17} \mathrm{It}$ exhibits a wide range of biological activities such as anti-inflammatory and antimicrobial, ${ }^{18}$ anti-oxidant, ${ }^{19}$ 
and potent anticholinesterase activity. ${ }^{20}$ Many researchers had focused on its anticholinesterase activity and synthesized many derivatives to potentiate this effect. ${ }^{20,21,22}$

Organophosphorous (OP) compounds are serine esterase and protease inhibitors widely used in agriculture and in industry as insecticides and as softening agents and additives respectively, and some of them are declared as chemical warfare agents. ${ }^{23}$ The mechanism of the toxic action of these insecticides in man and animals is the inhibition of cholinesterase (ChE) at the nerve terminals resulting in an accumulation of acetylcholine that subsequently causes a series of muscarinic, nicotinic and central nervous system effects. ${ }^{24,25}$

Chlorpyrifos (phosphorothionic acid O, O-diethyl 0-[3,5,6-trichloro-2-pyridyl] ester) is an OP insecticide and is considered by the U.S. Environmental Protection Agency to be moderately toxic. ${ }^{26}$

Chlorpyrifos is a weak and reversible inhibitor of ChE, and can protect, to a certain extent, the enzyme from inhibition by OP when administered before potent OP class compound. ${ }^{27}$

When weak inhibitors are injected together in vitro as a group before OP, showed some protective ability for the ChE against OP inhibitory effect. ${ }^{15}$ The putative mode of protective action of weak inhibitors is, when administered in excess, a competition for the active site of enzyme with the more potent organophosphate, this protective effect of weak inhibitors is thought to be of practical usefulness for the treatment of organophosphate poisoning. ${ }^{28}$

The purpose of this study was to synthesize two new series of derivatives of metoclopramide and diphenhydramine with coumarin by diazotization and replacement reactions and to quantify in vitro their protection effects on human blood cholinesterases using chlorpyrifos as a potent inhibitor.

\section{MATERIALS AND METHODS}

\section{Synthesis of metoclopramide and diphenhydramine derivatives:}

The parent compounds (metoclopramide and diphenhydramine) were supplied from Nenevah Drug Industry (Iraq). The coumarin derivatives used in this research were a gift from Professor Faris Thanon Abachi (College of Pharmacy/University of Mosul) and their purities were established by detecting their melting points. The solvents used were of analytical grade purity. The melting points were measured using an electro-thermal CIA 9300 apparatus, and were reported uncorrected. The IR spectra of the compounds in $\mathrm{KBr}$ pellets were recorded on a Buck 500 scientific FTIR spectrophotometer.

The ultraviolet-visible spectra was obtained via Carrywinn U.V. Varian U.V. - visible spectrophotometer. The chemical structures were drawn by Chemdraw
Office 2001 software. Thin-layer chromatography (TLC) was carried out on TLC plastic sheets silica gel 60 F5 pre-coated, $20 \times 20 \mathrm{~cm}$, layer thickness $0.2 \mathrm{~mm}$. The spots on the chromatograms were localized using U.V. light $(366 \mathrm{~nm})$. The solvent system employed for separation composed from chloroform: methanol $(90: 10)$.

\subsection{Synthesis of series I compounds ${ }^{29}$}

Metoclopramide hydrochloride (5.98 g, 0.02 mole) was dissolved in $70 \mathrm{ml}$ of water in a beaker, and the resulting solution was cooled by immersing in a bath of crushed ice. The cold solution of sodium nitrite (1.65 g, 0.024 mole) in $(25 \mathrm{ml})$ water was placed in a dropping funnel and then added drop wise into the stirred solution of metoclopramide hydrochloride in the ice bath; the reaction temperature was kept below $5^{\circ} \mathrm{C}$ by adding few grams of crushed ice when necessary. After the last addition of sodium nitrite, the resulting solution was stirred for 5 minutes in the ice bath. A drop of the solution diluted with four drops of water was tested with potassium iodide-starch paper; if no immediate blue color was obtained at the point of contact with paper, a further $1 \mathrm{ml}$ of sodium nitrite solution was added, and the solution tested again after 5 minutes. Further addition and testing were continued until an immediate blue color was obtained. Thus, the diazonium salt solution was prepared.

Coumarin derivative $(0.02$ mole) was dissolved in a $10 \%$ sodium hydroxide solution, and then it was cooled to $5-9^{\circ} \mathrm{C}$. The previously prepared diazonium salt solution was added drop wise to the basic solution of coumarin derivative during $15-30$ minutes at $0-5^{\circ} \mathrm{C}$, under a stirring and by adjusting the $\mathrm{pH}$ (8.5-9) with $15 \% \mathrm{Na}_{2} \mathrm{CO}_{3}$ solution. Then the obtained reaction mass was filtered. The precipitate was washed with $20 \% \mathrm{HCl}$ solution to remove the traces of unreacted amines and then with water up to neutral $\mathrm{pH}$. Then the precipitate was dried and recrystallized from ethanol: water (5:1).

The compound purity was checked by TLC, and its result showed that only a single spot was observed. ${ }^{30}$ The physicochemical properties of these compounds are listed in table 1.

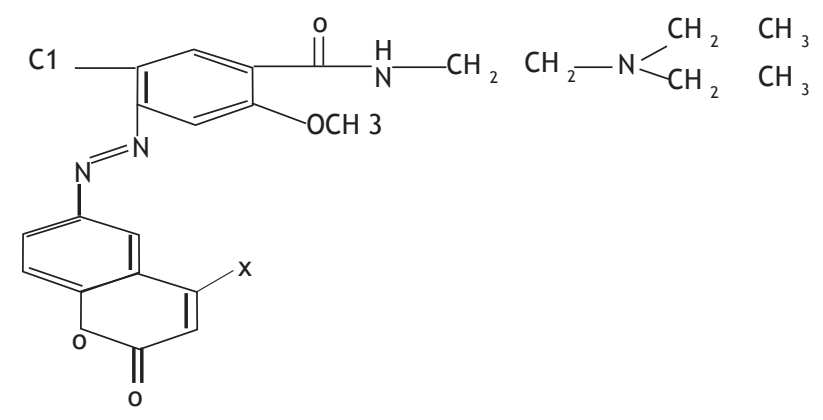

Compound 1, $\mathrm{X}=\mathrm{H}, 5$-Chloro-N-(2-diethylamino-ethyl)2-methoxy-4-(2-oxo-2H-chromen-6-ylazo)-benzamide. Compound 2, $\mathrm{X}=\mathrm{CH}_{3}, \quad 5$-Chloro- $\mathrm{N}$-(2-diethylaminoethyl)-2-methoxy-4-(4-methyl-2-oxo-2H-chromen6-ylazo)-benzamide. 


\subsection{Synthesis of series II compounds ${ }^{31}$}

Aminocoumarin (0.01 mole) was dissolved in 16\% aqueous hydrochloric acid (16 ml). To this solution was added drop wise a cold solution of sodium nitrite $(0.76$ $\mathrm{g}, 0.011 \mathrm{~mole})$ in water $(2 \mathrm{ml})$ with efficient stirring at $0-5^{\circ} \mathrm{C}$. After the last addition, the resulting solution was stirred for $5 \mathrm{~min}$ in an ice bath. A drop of the solution diluted with four drops of water was tested with potassium iodide-starch paper; if no immediate blue color was obtained at the point of contact with paper, a further $1 \mathrm{ml}$ of sodium nitrite solution was added, and the solution tested again after 5 minutes. Further addition and testing were continued until an immediate blue color was obtained. The clear diazonium salt solution was obtained and used immediately in the coupling reaction.
Diphenhydramine ( $2.55 \mathrm{~g}, 0.01$ mole) was dissolved in sodium hydroxide solution $(25 \mathrm{ml}, 10 \% \mathrm{w} / \mathrm{v})$. The solution was cooled to $3^{\circ} \mathrm{C}$ in an ice bath. To this well stirred solution, the above diazonium solution was added drop wise and the temperature kept below $5^{\circ} \mathrm{C}$. The reaction mass was further stirred for two hours at $5^{\circ} \mathrm{C}$ maintaining the $\mathrm{pH}$ at 8.0 by adding required amount of $10 \% \mathrm{w} / \mathrm{v}$ of sodium carbonate solution. The reaction mass was diluted with $80 \mathrm{ml}$ hot water until the washings were neutral. Then diluted solution of $\mathrm{HCl}$ was added drop wise. The product was filtered off, dried and recrystallized from ethanol. The compound purity was checked by TLC, and its result showed that only a single spot was observed..$^{32}$ The physicochemical properties of these compounds are listed in table 1.

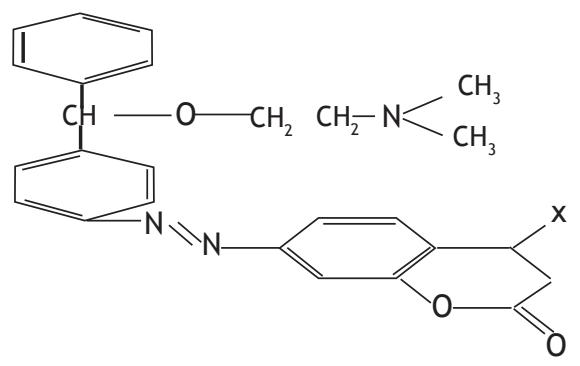

Compound 3, $\mathrm{X}=\mathrm{H}, 7-\{4-[(2-D i m e t h y l a m i n o-e t h o x y)$-phenyl-methyl]-phenylazo\}-chromen-2-one Compound 4, $\mathrm{X}=\mathrm{CH}_{3}, 7$-\{4-[(2-Dimethylamino-ethoxy)-phenyl-methyl]-phenylazo $\}$-4-methyl-chromen-2-one

Table 1. Physicochemical properties of the synthesized series I and II compounds

\begin{tabular}{lllll}
\hline Compound no. & m.p. $\left({ }^{\circ} \mathrm{C}\right)$ & \%yield & $\mathrm{Rf}$ & $\lambda$ max ethanol $(\mathrm{nm})$ \\
\hline Compound 1 & $168-170$ & 66 & 0.09 & 463 \\
Compound 2 & $182-184$ & 62 & 0.072 & 460 \\
Compound 3 & $181-183$ & 57 & 0.36 & 486 \\
Compound 4 & $191-193$ & 51 & 0.35 & 481
\end{tabular}

\section{In vitro assay of the ChE protection ability:}

The subjects included in this study (male and females, age $30+/-10$ years) were apparently healthy with no history of exposure to OP insecticides. Blood samples were collected in the $5 \mathrm{ml}$ EDTA-treated test tubes and then centrifuged by Centurion (UK) at $3000 \mathrm{rpm}$ for 15 minutes. The erythrocytes and plasma were pooled and kept in ice for the ChE assay.

\subsection{Electrometric assay of ChE activity. ${ }^{33-35}$}

The reaction mixture in a $10 \mathrm{ml}$ beaker contained $3 \mathrm{ml}$ of distilled water, $0.2 \mathrm{ml}$ of plasma or erythrocytes and $3 \mathrm{ml}$ of $\mathrm{pH} 8.1$ barbital-phosphate buffer was prepared, and its $\mathrm{pH}(\mathrm{pH} 1)$ was measured with glass electrode using $\mathrm{pH}$ meter. Then $0.1 \mathrm{ml}$ of aqueous acetylcholine solution $7.5 \%$ was added and the reaction mixture was incubated at $37^{\circ} \mathrm{C}$ in a water bath for 20 minutes. After that, the $\mathrm{pH}$ of reaction mixture $(\mathrm{pH} 2)$ was measured, and the enzyme activity was calculated as follows:

ChE activity $(\Delta \mathrm{pH} / 20 \mathrm{~min})=.(\mathrm{pH} 1-\mathrm{pH} 2)-\Delta \mathrm{pH}$ of blank
The blank was without the blood aliquot. The barbitalphosphate buffer solution was prepared from 1.24 $\mathrm{g}$ sodium barbital, $0.163 \mathrm{~g}$ potassium dihydrogen phosphate and $35.07 \mathrm{~g}$ sodium chloride in a one liter of distilled water; the $\mathrm{pH}$ of buffer solution was adjusted to 8.1 with $0.5 \mathrm{~N} \mathrm{HCl}$.

2.2 In vitro ChE inhibition by the metoclopramide and diphenhydramine derivatives and Chlorpyrifos. ${ }^{36}$ Plasma and erythrocyte samples were collected from healthy volunteers and different concentrations of the new derivatives were prepared and then added individually in a volume of $0.1 \mathrm{ml}$ to the reaction mixture to obtain the final concentrations as following: Chlorpyriphos : $4 \mu \mathrm{M}$

Compound $1: 200,100,50$ and $25 \mu M$

Compound $2: 200,100,50$ and $25 \mu \mathrm{M}$

Compound $3: 200,100,50$ and $25 \mu \mathrm{M}$

Compound $4: 200,100,50$ and $25 \mu M$ 
Chlorpyriphos or metoclopramide and diphenhydramine derivatives were prepared in distilled water and individually added in a $0.1 \mathrm{ml}$ to the reaction mixture of the plasma and erythrocytes. The reaction mixture containing chlorpyriphos or metoclopramide and diphenhydramine derivatives was incubated at $37^{\circ} \mathrm{C}$ for 10 minutes. Thereafter, the residual ChE activity was measured and the \% of enzyme inhibition was calculated as follows:

$$
\% \text { ChE inhibition }=\left[\mathrm{ChE}_{1}-\mathrm{ChE}_{2}\right] / \mathrm{ChE}_{1} \times 100
$$

Where $\mathrm{ChE}_{1}$ is the enzyme activity without chlorpyriphos or metoclopramide and diphenhydramine (control) while $\mathrm{ChE}_{2}$ is the enzyme activity with chlorpyriphos or metoclopramide and diphenhydramine (inhibitor).

\subsection{In vitro ChE inhibition by the metoclopramide and} diphenhydramine derivatives with Chlorpyriphos in the same sample. ${ }^{37}$

The same plasma and erythrocyte samples used in the previous experiment were used here and the same concentrations of metoclopramide and diphenhydramine derivatives were also applied. $0.1 \mathrm{ml}$ of each derivative concentration mentioned above was added to the reaction mixture which was incubated at $37^{\circ} \mathrm{C}$ in a water bath for 10 minutes, then chlorpyriphos diluted with distilled water $0.1 \mathrm{ml}, 4$ $\mu \mathrm{M}$ was added after 10 minutes from the addition of the metoclopramide or diphenhydramine derivatives, then the reaction mixture was again incubated at $37^{\circ} \mathrm{C}$ in a water bath for 10 minutes before the ChE activity and percentage of enzyme inhibition were calculated as mentioned above.

\section{Statistical Analysis:}

When applicable, the data were subjected to analysis of variance followed by the least of significant difference test. ${ }^{38}$ Paired Student's t-test were used for the means of two groups. ${ }^{39}$ The level of significance was at $P<0.05$.

\section{RESULTS}

The data obtained from IR spectra of series I and II compounds to further confirm the production of the new derivatives are listed in table 2.

Table 2. The data obtained from IR spectra of series I and II compounds.

\begin{tabular}{|c|c|c|c|c|c|c|}
\hline \multirow{2}{*}{$\begin{array}{l}\text { Compound } \\
\text { number }\end{array}$} & \multicolumn{6}{|c|}{ The stretching absorption band $\left(\mathrm{KBr}, \mathrm{v}, \mathrm{cm}^{-1}\right)$} \\
\hline & $\begin{array}{l}\mathrm{C}=\mathrm{O} \text { of } \\
\text { amide }\end{array}$ & $\begin{array}{l}\mathrm{C}=\mathrm{O} \text { of } \\
\mathrm{a} \text {-pyrone }\end{array}$ & $\begin{array}{l}\mathrm{C}-\mathrm{H} \\
\text { aromatic }\end{array}$ & $\begin{array}{l}C=C \text { of } \\
\alpha-\text { pyrone }\end{array}$ & $\begin{array}{l}\mathrm{N}-\mathrm{H} \text { of } \\
\text { amide bond }\end{array}$ & $\begin{array}{l}\text { Ar-O-R } \\
\text { ether }\end{array}$ \\
\hline 1 & $\begin{array}{l}1608 \\
\text { strong }\end{array}$ & $\begin{array}{l}1735 \\
\text { strong }\end{array}$ & $\begin{array}{l}3041 \\
\text { weak }\end{array}$ & $\begin{array}{l}1668 \\
\text { strong }\end{array}$ & $\begin{array}{l}3078,3292 \\
\text { medium }\end{array}$ & $\begin{array}{l}1227 \\
\text { strong }\end{array}$ \\
\hline 2 & $\begin{array}{l}1598 \\
\text { strong } \\
\text { C-H of } \\
\text { methyl group }\end{array}$ & $\begin{array}{l}1737 \\
\text { strong } \\
C=0 \text { of } \\
\text { a-pyrone }\end{array}$ & $\begin{array}{l}3057 \\
\text { weak } \\
\text { C-H } \\
\text { aromatic }\end{array}$ & $\begin{array}{l}1665 \\
\text { strong } \\
C=C \text { of } \\
\text { a- pyrone }\end{array}$ & $\begin{array}{l}3071,3291 \\
\text { medium } \\
\text { C-N of } \\
\text { tertiary amine }\end{array}$ & $\begin{array}{l}1231 \\
\text { strong } \\
\text { R-O-R } \\
\text { ether }\end{array}$ \\
\hline 3 & -.-.-.-- & $\begin{array}{l}1732 \\
\text { strong }\end{array}$ & $\begin{array}{l}3046 \\
\text { weak }\end{array}$ & $\begin{array}{l}1664 \\
\text { strong }\end{array}$ & $\begin{array}{l}1150 \\
\text { medium }\end{array}$ & $\begin{array}{l}1225 \\
\text { strong }\end{array}$ \\
\hline 4 & $\begin{array}{l}2773 \\
\text { medium }\end{array}$ & $\begin{array}{l}1731 \\
\text { strong }\end{array}$ & $\begin{array}{l}3023 \\
\text { weak }\end{array}$ & $\begin{array}{l}1661 \\
\text { strong }\end{array}$ & $\begin{array}{l}1153 \\
\text { medium }\end{array}$ & $\begin{array}{l}1226 \\
\text { strong }\end{array}$ \\
\hline
\end{tabular}

The in vitro inhibition of plasma and erythrocyte ChE activities by Chlorpyriphos ( $4 \mu \mathrm{M})$ and compounds $1,2,3$ and 4 in different concentrations, and then each concentration of these compounds with chlorpyriphos were monitored; the results of these studies are shown in the tables 3 and 4. 
Table 3. In vitro inhibition of human plasma and erythrocyte cholinesterase activities by compounds 1 and 2 and their effects on ChEs inhibition by chlorpyriphos

\begin{tabular}{|c|c|c|c|c|}
\hline \multirow[b]{2}{*}{ Compound $1(\mu \mathrm{M})$} & \multicolumn{2}{|c|}{ Plasma ChE } & \multicolumn{2}{|c|}{ Erythrocyte ChE } \\
\hline & $\Delta \mathrm{pH} / 20 \mathrm{~min}$ & \% Inhibition & $\Delta \mathrm{pH} / 20 \min$ & $\%$ Inhibition \\
\hline $0 \mu \mathrm{M}$ & $1.07 \pm 0.009$ & 0 & $1.16 \pm 0.008$ & 0 \\
\hline chlorpyriphos $4 \mu \mathrm{M}$ & $0.01 \pm 0.002^{*}$ & 90.65 & $0.88 \pm 0.001^{*}$ & 24.19 \\
\hline $\begin{array}{l}25 \mu M+ \\
25 \mu M \text { before } \neq\end{array}$ & $0.22 \pm 0.016^{*}$ & 32.48 & $0.98 \pm 0.006^{*}$ & 15.93 \\
\hline $\begin{array}{l}\text { chlorpyriphos } 4 \\
\mu \mathrm{M}\end{array}$ & $0.21 \pm 0.012^{*} a$ & 100 & $0.98 \pm 0.016^{*} a$ & 15.24 \\
\hline $\begin{array}{l}50 \mu M+ \\
50 \mu M \text { before } \neq\end{array}$ & $0.25 \pm 0.041^{*}$ & 47.66 & $0.95 \pm 0.014^{*}$ & 18.10 \\
\hline $\begin{array}{l}\text { chlorpyriphos } 4 \\
\mu M\end{array}$ & $0.16 \pm 0.005^{*}$ & 100 & $0.96 \pm 0.002^{*} a$ & 17.24 \\
\hline $\begin{array}{l}100 \mu \mathrm{M}+ \\
100 \mu \mathrm{M} \text { before } \ddagger\end{array}$ & $0.25 \pm 0.011^{*}$ & 69.16 & $0.88 \pm 0.001^{*}$ & 24.13 \\
\hline $\begin{array}{l}\text { chlorpyriphos } 4 \\
\mu M\end{array}$ & $0.17 \pm 0.022^{*}$ & 100 & $0.75 \pm 0.012^{*} a$ & 35.78 \\
\hline $\begin{array}{l}200 \mu M+ \\
200 \mu M \text { before } \ddagger\end{array}$ & $0.05 \pm 0.01^{*}$ & 64.49 & $0.49 \pm 0.011^{*}$ & 57.76 \\
\hline $\begin{array}{l}\text { chlorpyriphos } 4 \\
\mu \mathrm{M}\end{array}$ & $0.33 \pm 0.002^{*} a$ & 100 & 0.89 v0.012* & 23.28 \\
\hline
\end{tabular}

\begin{tabular}{|c|c|c|c|c|}
\hline \multirow[b]{2}{*}{ Compound 2 ( $\mu \mathrm{M})$} & \multicolumn{2}{|c|}{ Plasma ChE } & \multicolumn{2}{|c|}{ Erythrocyte ChE } \\
\hline & $\Delta \mathrm{pH} / 20 \mathrm{~min}$ & \% Inhibition & $\Delta \mathrm{pH} / 20 \min$ & \% Inhibition \\
\hline $0 \mu \mathrm{M}$ & $1.07 \pm 0.09$ & 0 & $1.16 \pm 0.008$ & 0 \\
\hline chlorpyriphos $4 \mu \mathrm{M}$ & $0.1 \pm 0.002^{*}$ & 90.65 & $0.88 \pm 0.001^{*}$ & 24.19 \\
\hline $25 \mu M_{+}$ & $0.72 \pm 0.003$ & 32.48 & $0.98 \pm 0.006^{*}$ & 15.93 \\
\hline $\begin{array}{l}25 \mu \mathrm{M} \text { before } \ddagger \\
\text { chlorpyriphos } 4 \mu \mathrm{M}\end{array}$ & $0.00 \pm 0.0^{*}$ & 100 & $0.98 \pm 0.016^{*} a$ & 15.24 \\
\hline $50 \mu \mathrm{M}+$ & $0.56 \pm 0.001^{*}$ & 47.66 & $0.95 \pm 0.014^{*}$ & 18.10 \\
\hline $\begin{array}{l}50 \mu \mathrm{M} \text { before } \ddagger \\
\text { chlorpyriphos } 4 \mu \mathrm{M}\end{array}$ & $0.00 \pm 0.0^{*}$ & 100 & $0.96 \pm 0.002^{*} a$ & 17.24 \\
\hline $100 \mu M_{+}$ & $0.33 \pm 0.021$ & 69.16 & $0.88 \pm 0.001^{*}$ & 24.13 \\
\hline $\begin{array}{l}100 \mu M \text { before } \neq \\
\text { chlorpyriphos } 4 \mu M\end{array}$ & $0.00 \pm 0.00^{*}$ & 100 & $0.75 \pm 0.012^{*} a$ & 35.78 \\
\hline $200 \mu M+$ & $0.38 \pm 0.013$ & 64.49 & $0.49 \pm 0.011^{*}$ & 57.76 \\
\hline $\begin{array}{l}200 \mu \mathrm{M} \text { before } \ddagger \\
\text { chlorpyriphos } 4 \mu \mathrm{M}\end{array}$ & $0.00 \pm 0.00^{*}$ & 100 & $0.89 \pm 0.012^{*}$ & 23.28 \\
\hline
\end{tabular}

$\mathrm{N}=2-3$ / concentration groups.

ChE values are means $\pm \mathrm{SE}$

+ Cholinesterase inhibition was detected after 10 min incubation of the sample with compound 1 and 2 .

₹ compound 1 and 2 were added to the reaction mixture 10 min before the chlorpyriphos addition.

* Significantly different from the respective control (0) group, $\mathrm{P}<0.05$

a Significantly different from the chlorpyriphos $(4 \mu \mathrm{M}), \mathrm{P}<0.05$ 
Table 4. In vitro inhibition of human plasma and erythrocyte cholinesterase activities by compounds 3 and 4 and their effects on ChEs inhibition by chlorpyriphos

\begin{tabular}{|c|c|c|c|c|}
\hline \multirow[b]{2}{*}{ Compound $3(\mu M)$} & \multicolumn{2}{|c|}{ Plasma ChE } & \multicolumn{2}{|c|}{ Erythrocyte ChE } \\
\hline & $\Delta \mathrm{pH} / 20 \min$ & \% Inhibition & $\Delta \mathrm{pH} / 20 \min$ & \% Inhibition \\
\hline $\begin{array}{l}0 \mu \mathrm{M} \\
\text { chlorpyriphos } 4 \mu \mathrm{M}\end{array}$ & $1.07 \pm 0.009$ & 0 & $1.16 \pm 0.008$ & 00 \\
\hline $25 \mu M+$ & $0.1 \pm 0.005^{*}$ & 90.65 & $0.88 \pm 0.001^{*}$ & 24.19 \\
\hline $\begin{array}{l}25 \mu \mathrm{M} \text { before } \neq \\
\text { chlorpyriphos } 4 \mu \mathrm{M}\end{array}$ & $0.57 \pm 0.015^{*}$ & 46.29 & $0.99 \pm 0.002^{*}$ & 14.71 \\
\hline $50 \mu \mathrm{M}+$ & $0.19 \pm 0.03^{*} a$ & 82.07 & $1.01 \pm 0.035^{*} a$ & 12.81 \\
\hline $\begin{array}{l}50 \mu M \text { before } \neq \\
\text { chlorpyriphos } 4 \mu M\end{array}$ & $0.46 \pm 0.008^{*}$ & 57.01 & $0.97 \pm 0.015^{*}$ & 16.38 \\
\hline $100 \mu \mathrm{M}+$ & $0.2 \pm 0.01^{*} \mathrm{a}$ & 81.31 & $0.99 \pm 0.026^{*} a$ & 14.66 \\
\hline $100 \mu M$ before $\ddagger$ & $0.36 \pm 0.002^{*}$ & 66.36 & $0.95 \pm 0.011^{*}$ & 18.10 \\
\hline chlorpyriphos $4 \mu \mathrm{M}$ & $0.19 \pm 0.012^{*} a$ & 82.24 & $0.96 \pm 0.017^{*} a$ & 17.24 \\
\hline $200 \mu \mathrm{M}+$ & $0.26 \pm 0.031^{*}$ & 75.70 & $0.95 \pm 0.012^{*}$ & 18.10 \\
\hline $\begin{array}{l}200 \mu \mathrm{M} \text { before } \ddagger \\
\text { chlorpyriphos } 4 \mu \mathrm{M}\end{array}$ & $0.15 \pm 0.04^{*}$ & 85.98 & $0.83 \pm 0.012^{*}$ & 28.45 \\
\hline
\end{tabular}

\begin{tabular}{|c|c|c|c|c|}
\hline \multirow[b]{2}{*}{ Compound $4(\mu M)$} & \multicolumn{2}{|c|}{ Plasma ChE } & \multicolumn{2}{|c|}{ Erythrocyte ChE } \\
\hline & $\Delta \mathrm{pH} / 20 \mathrm{~min}$ & \% Inhibition & $\Delta \mathrm{pH} / 20 \min$ & \% Inhibition \\
\hline $\begin{array}{l}0 \mu \mathrm{M} \\
\text { chlorpyriphos } 4 \mu \mathrm{M}\end{array}$ & $\begin{array}{l}1.07 \pm 0.009 \\
0.1 \pm 0.016^{*}\end{array}$ & $\begin{array}{l}00 \\
90.65 \\
3\end{array}$ & $\begin{array}{l}1.16 \pm 0.008 \\
0.88 \pm 0.027^{*}\end{array}$ & $\begin{array}{l}0 \\
24.19\end{array}$ \\
\hline $\begin{array}{l}25 \mu M+ \\
25 \mu M \text { before } \neq \\
\text { chlorpyriphos } 4 \mu M\end{array}$ & $\begin{array}{l}0.73 \pm 0.015^{*} \\
0.21 \pm 0.01^{*} a\end{array}$ & $\begin{array}{l}1.58 \\
80.11\end{array}$ & $\begin{array}{l}1.06 \pm 0.017 \\
0.80 \pm 0.015^{*}\end{array}$ & $\begin{array}{l}8.05 \\
30.82\end{array}$ \\
\hline $\begin{array}{l}50 \mu M+ \\
50 \mu M \text { before } \neq \\
\text { chlorpyriphos } 4 \mu M\end{array}$ & $\begin{array}{l}0.54 \pm 0.008^{*} \\
0.17 \pm 0.02^{*}\end{array}$ & $\begin{array}{l}49.53 \\
84.11\end{array}$ & $\begin{array}{l}1.04 \pm 0.006 \\
0.79 \pm 0.006^{*} a\end{array}$ & $\begin{array}{l}10.35 \\
40.52\end{array}$ \\
\hline $\begin{array}{l}100 \mu M+ \\
100 \mu M \text { before } \neq \\
\text { chlorpyriphos } 4 \mu M\end{array}$ & $\begin{array}{l}0.39 \pm 0.001^{*} \\
0.11 \pm 0.012^{*}\end{array}$ & $\begin{array}{l}63.55 \\
89.72\end{array}$ & $\begin{array}{l}1 \pm 0.011^{*} \\
0.61 \pm 0.017^{*} a\end{array}$ & $\begin{array}{l}13.79 \\
47.41\end{array}$ \\
\hline $\begin{array}{l}200 \mu M+ \\
200 \mu M \text { before } \ddagger \\
\text { chlorpyriphos } 4 \mu M\end{array}$ & $\begin{array}{l}0.14 \pm 0.011^{*} \\
0.19 \pm 0.03^{*} \mathrm{a}\end{array}$ & $\begin{array}{l}86.92 \\
82.24\end{array}$ & $\begin{array}{l}1 \pm 0.002^{*} \\
1.08 \pm 0.012^{*} a\end{array}$ & $\begin{array}{l}13.79 \\
15.52\end{array}$ \\
\hline
\end{tabular}

$\mathrm{N}=2-3$ / concentration groups.

ChE values are means \pm SE

+ Cholinesterase inhibition was detected after 10 min incubation of the sample with compound 3 and 4 .

₹ compound 3 and 4 were added to the reaction mixture 10 min before the chlorpyriphos addition.

* Significantly different from the respective control (0) group, $\mathrm{P}<0.05$

a Significantly different from the chlorpyriphos $(4 \mu \mathrm{M}), \mathrm{P}<0.05$ 


\section{DISCUSSION}

\subsection{The infrared spectra of series I compounds}

The disappearance of a weak absorbance band at $v$ $3403 \mathrm{~cm}^{-1}$ and medium absorbance band at $v 3481$ $\mathrm{cm}^{-1}$ of the primary amine of metoclopramide and the appearance of weak bands at $v 1430 \mathrm{~cm}-1$ and at v $1428 \mathrm{~cm}^{-1}$ attributed to unsymmetrical azo bonds confirmed the formation of compound 1 and 2. Table 2 shows some of the characteristic absorption bands present in an IR spectra of series I compounds.

\subsection{The infrared spectra of the series II compounds} The disappearance of a weak absorbance band at $v$ $3434 \mathrm{~cm}^{-1}$ and medium absorbance band at $v 3467$ $\mathrm{cm}^{-1}$ of the primary amine of 7-aminocoumarin and the appearance of a weak band at $\vee 1431 \mathrm{~cm}^{-1}$ attributed to unsymmetrical azo bond confirmed the formation of compound 3. The disappearance of a weak absorbance band at $\vee 3433 \mathrm{~cm}^{-1}$ and medium absorbance band at $v 3470 \mathrm{~cm}^{-1}$ of the primary amine of 7-amino 4-methyl coumarin and the appearance of a weak band at $v 1430$ $\mathrm{cm}-1$ attributed to unsymmetrical azo bond confirmed the formation of compound 4. Table 2 shows some of the characteristic absorption bands present in an IR spectra of series II compounds.

\subsection{In vitro assay studies:}

Depending on the good correlation between ChE inhibition in vivo and in vitro, ${ }^{40}$ this study conducted to further clear the idea that says: weak or reversible ChE inhibitors could reduce or prevent the toxicity of the strong ChE inhibitors (OP) when introduced before14 and not after it. $1^{5,36}$

In the previous work, some change in the functional groups of was made in order to potentiate its protection ability of ChE against OP. ${ }^{41}$ The presented work aimed to further intensify the protection ability of two-week ChE inhibitors (diphenhydramine and metoclopramide) by synthesizing two series of compounds, one containing metoclopramide and coumarin and the other consist of diphenhydramine and coumarin in different ways of conjugation to give different compounds that differ in their functional group position so as to compete with the OP at the enzyme sites (i.e. two molecules conjugate together and both having the ability to attach the enzyme). The study proposed that each molecule of the new compounds may catch and protect at the same time two ChE moieties from OP (this is the theoretical idea, to synthesis a weak ChE inhibitor that has little inhibitory effect, few side effects, and with high affinity to protect the enzyme from the $\mathrm{OP}$ ).

The in vitro test of the affinity of these new compounds to conjugate the enzyme moiety came with good results at different concentrations; these compounds inhibited ChE activity at different percentages, depending on their selectivity for the enzyme and the affinity power of the chemical group that was modified.

Furthermore, all the compounds showed more selectivity for plasma ChE (BChE) more than for the erythrocyte ChE (AChE). This may be because the parent compounds had similar selectivity.

According to Table 3, compound 1 when used alone showed similar inhibitory effect and selectivity as the chlorpyriphos for both plasma and erythrocyte ChE. While when used with chlorpyriphos, compound 1 decreased the inhibitory effect of chlorpyriphos especially at $25 \mu \mathrm{M}$ and $200 \mu \mathrm{M}$ concentrations, as they reduced the plasma, ChE inhibition to level even less than that caused by the chlorpyriphos or compound 1 alone (show some protection ability). However, this can't be seen in the erythrocyte ChE as compound 1 increased the ChE inhibition to be more than that for both the compound 1 and chlorpyriphos when used alone. (i.e. compound 1 showed protection ability for BChE and not for AChE especially at $200 \mu \mathrm{M}$ concentration).

For compound 2, the picture is different as the selectivity and the affinity of the compound become less than that caused by chlorpyriphos when used alone for both plasma and erythrocyte. However, when used together (chlorpyriphos and compound 2) the inhibition of plasma ChE increased and reached a maximum level of $100 \%$ for all concentrations. On the other hand, compound 2 decreased the erythrocyte ChE inhibition of chlorpyriphos and stabilized the inhibition when used alone (prevented the chlorpyriphos from reaching the enzyme or so as to say it covered the enzyme moiety). This can especially be seen at $25 \mu \mathrm{M}$ and $50 \mu \mathrm{M}$ concentrations. Furthermore, the $200 \mu \mathrm{M}$ concentration decreased the inhibition to less than that caused by the chlorpyriphos or compound 2 when used alone (Table 3 ), (i.e. compound 2 shows protection ability for $\mathrm{AChE}$ and not for $\mathrm{BChE}$ especially at $25 \mu \mathrm{M}, 50 \mu \mathrm{M}$ and $200 \mu \mathrm{M}$ ).

Table 4 reflects the picture of compound 3 as when used alone showed inhibitory action and affinity to the enzyme more than that of compound 2 for plasma ChE and the same for compound 2 for the erythrocyte ChE, although in both cases, the inhibition is less than that caused by chlorpyriphos when used alone. And when it was used with chlorpyriphos some protection ability can be seen as it decreased plasma ChE inhibition caused by chlorpyriphos to a significant degree but still more than when used alone. Furthermore, for erythrocyte ChE, compound 3 decreased the chlorpyriphos inhibitory effect also to a significant degree and even less than that caused by compound 3 when used alone (it may conjugate chlorpyriphos and prevent its attachment to the enzyme moiety, or it may bind the enzyme in a manner that prevents chlorpyriphos from reaching the enzyme moiety "protection"). This can be shown by the $25 \mu \mathrm{M}, 50 \mu \mathrm{M}$ and $100 \mu \mathrm{M}$ concentrations for both plasma and erythrocyte ChE (Table 4), (i.e. compound 3 show protection ability for both BChE and AChE for all concentration "maximum protections").

The picture for compound 4 shows some difference as the affinity for both plasma and erythrocyte ChE of compound 4 was lower than that of the other compounds 
and less than that of chlorpyriphos when used alone (low inhibitory effect for ChE when used alone). When used with chlorpyriphos, compound 4 decreased the inhibition of plasma ChE caused by chlorpyriphos to a significant degree as for compound 3 but still the inhibition more than that caused by the compound 4 alone, except $200 \mu \mathrm{M}$ concentration, which decreased the chlorpyriphos inhibitory action lower than that when it was used alone. Furthermore, the picture for compound 4 shows more differences as it increases the inhibition of erythrocyte ChE caused by chlorpyriphos when used with it and intensify such effect to more than that caused by chlorpyriphos or compound 4 when

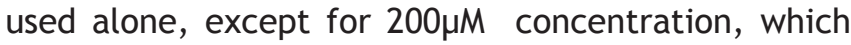
decreased the inhibition of erythrocyte ChE caused by chlorpyriphos to a significant degree which is less than that caused by chlorpyriphos and compound 4 when used alone, (i.e. compound 4 showed some protection ability for $\mathrm{BChE}$ but not for $\mathrm{AChE}$ for all concentrations except the $200 \mu \mathrm{M}$ concentration that showed maximum protection as compound 3 ).

\section{CONCLUSION}

Metoclopramide derivatives with coumarin show selectivity protection for ChE against chlorpyriphos inhibitory effect as one derivative protected $\mathrm{BChE}$ and increased the inhibition of the AChE, and the other derivative show the opposite. While diphenhydramine derivatives with coumarin show more protective ability for both $\mathrm{BChE}$ and $\mathrm{AChE}$ as the compound 3 showed the maximum protection for all concentration, but the other derivative (compound 4) showed different activity manner as the low concentrations acted for metoclopramide derivatives while the high concentrations acted for first diphenhydramine derivatives (protected both $\mathrm{AChE}$ and $\mathrm{BChE}$ ).

\section{REFERENCES}

1. Wilson BW, Henderson JD. Blood esterase determi nations as markers of exposure. Rev Environ Con tam Toxicol 1992; 128:55-69.

2. Lotti M. The pathogenesis of organophosphate poly neuropathy. CRC Crit Rev Toxicol 1992; 21:465-88.

3. Narayanan V, Manu RS. Motility disorders of gastrointestinal tract. Indian Journal of Pediatrics 2006; 73:927-30.

4. Graham SG, Crossley AW. The characteristics of the Inhibition of serum cholinesterase by metoclo pramide. Eur J Clin Pharmacol 1995; 48:225-8.

5. Chemnitius JM, Haselmeyer KH, Gonska BD, Kreu zer H, Zech R. Indirect parasympathomimetic ac tivity of metoclopramide: reversible inhibition of cholinesterases from human central nervous system and blood. Pharmacol Res 1996; 34:65-72.

6. Petroianu GA, Hasan MY, Kosanovic M, Vijayasara thy $C$, Saleh AM. Metoclopramide protection of cho linesterase from paraoxon inhibition. Vet Hum Toxi col 2003; 45:251 -3.

7. Coggon D. Work with pesticides and organophos phate. Occup Med 2002; 52:467-70.

8. Petroianu GA, Hasan MY, Nurulain SM, et al. Pro tective drugs in acute large-dose exposure to orga no phosphates: a comparison of metoclopramide and tiapride with pralidoxime in rats. Anesth Analg 2005; 100:382-6.

9. Petroianu GA, Hasan MY, Arafat K, Nurulain SM and Schmitt A. Weak inhibitors protect cholinesterases from strong inhibitors (paraoxon): in vitro effect of tiapride. J Appl Toxicol 2005; 25:562-7.

10.BNF. British National Formulary 56. British Medical Association, Royal Pharmaceutical Society of Great Britain, United Kingdom, 2008.

11. Laurence DR, Bennett PN, Brown MJ. Clinical Pharmacology. 9th ed.New York: Churchill Livingstone, 2006: 267-311.

12. Potter WZ, Hollister LE. Antihistaminic agents. In: Katzung, BG, ed. Basic and Clinical Pharmacology. 9th Edition. New York: Lange Medical Books/Mc Graw Hill 2007: 564-611.

13. Al-Baggou' BK, Mohammad FK. Antagonism of methomyl-induced toxicosis by diphenhydramine in rats. Environ Toxicol Pharmacol 1999; 7:119-25.

14. Al-Baggou, BK, Mohammad FK. Effects of histamine $\mathrm{H} 1$ antagonists on the acute toxicity of physostigmine and neostigmine in mice. Iraqi J Vet Sci 1998; 11:147-54.

15. Mahmood AAJ. In vitro inhibition of human blood cholinesterases and protection against chlorpyriphos (organophosphate) by weak anticholines terase drugs. Iraqi J Pharm 2011; 11:18-29.

16. Bird SB, Gaspari RJ, Lee WJ, Dickson EW. Diphen hydramine as a protective agent in a rat model of acute lethal organophosphate poisoning. Acad Emerg Med 2002; 9:1369-72.

17. Kumar V, Tomar S, Patel RS, et al. FeCl3-catylased Pechmann synthesis of Coumarins in ionic liquids. Synthetic Communications 2008, 38: 2646-2654

18. Arshad A, Osman H, Bagley MC, et el. Synthesis and antimicrobial properties of some new thiazolyl coumarin derivatives. Eur J Med Chem 2011; 46:3788.

19. Roussaki M, Kontogiorgis CA, Hadjipavlou-Litina D, Hamilakis S, Detsi A. A novel synthesis of 3-aryl coumarins and evaluation of their anti oxidant and lipoxygenase inhibitory activity. Bioorg Med Chem Lett 2010; 20: 3889-92.

20. Alipour M1, Khoobi M, Foroumadi A, et al. Novel coumarin derivatives bearing $\mathrm{N}$-benzyl pyridinium moiety: potent and dual binding site acetylcholin esterase inhibitors. Bioorg Med Chem. 2012; 20:7214-22.

21. Zhou X, Wang XB, Wang T, Kong LY. Design, syn thesis, and acetylcholinesterase inhibitory activity of novel coumarin analogues. Bioorg Med. Chem 2008; 16:8011-21.

22. Fallarero A, Oinonen P, Gupta S. Inhibition of acetylcholinesterase by coumarins: the case of coumarin 106. Pharmacol Res 2008; 58:215-21.

23. Wiener SW, Hoffman RS. Nerve agents: a comprehensive review. J. Intensive Care Med 2004; 19:22- 37.

24. Bajgar J. Organophosphates/nerve agent poisoning: mechanism of action, diagnosis, 
prophylaxis and treatment. Adv Clin Chem 2004; 38:151-216.

25. Rusyniak DE, Nanagas KA. Organophosphate poisoning. Semin Neurol 2004; 24:197-204.

26. Doran WJ, Gregory Cope W, Rada RG, Sandheinrich MB. Acetyl cholinesterase inhibition in the threeridge mussel (Amblema plicata) by chlorpyrifos: implications for biomoni toring. Ecotoxicol Environ Saf 2001; 49:91-8.

27. Petroianu G, Kühn F, Thyes C, Ewald V, Missler A. In vitro protection of plasma cholinesterases by metoclopramide from inhibition by paraoxon. J Appl Toxicol 2003; 23:75-9.

28. Hasan MY, Nurulain SM, Arafat K, Naseer OP, Petroianu GA. In vivo metoclopramide protection of cholinesterase from paraoxon inhibition: direct comparison with pralidoxime in subchronic low-dose exposure. J Appl Toxicol 2004; 24:25760.

29. Mishra HP, Panigrahis S, Pramila KM, et al. Micellar catalysed iodo-dediazoniation reactions. Indian J Chem 2006; 45:2140-2.

30. Shahinian EGH, Haiduc I, Sebe I. Synthesis and characterization of new azo coumarin dyes. UPB Sci Bull 2011; 73:154-60.

31. Mustafa MS, El-Abadelah MM, Zihlif MA, Naffa RG, Mubarak MS. Synthesis and antitumor activity of some N1-(Coumarin-7-yl) amidrazones and related congeners. Molecules 2011; 16:4305-17.

32. Sanjay FT, Dinesh MP, Manish PP, Ranjan GP. Synthesis and antibacterial activity of new pyrazolo [3,4-b] quinoline based heterocyclic azo compounds and their dyeing performance. J Saudi Pharmaceut 2007; 15:48-54.

33. Mohammad FK, Faris GA, Al-Kassim NA. A modified electrometric method for measurement of erythrocyle acetylcholinesterase activity. Vet Hum Toxicol 1997; 39:337-9.

34. Ahmed OA, Mohammad FK. A simplified electro metric technique for rapid measurement of human blood cholinesterase activity. Internet J Toxicol 2005; 2:55-8.

35. Mohammad FK, Alias AS, Ahmed OA.

Electrometric measurement of plasma, erythrocyte and whole blood cholinesterase activities in healthy human volunteers. J Med Toxicol 2007; 3:25-30.

36. Mahmood AA. Interaction of phenothiazines with dichlorvos (cholinesterase inhibitors) in vitro study. M.Sc. Thesis, College of Pharmacy, University of Mosul, Mosul 2005. [unpublished]

37. Al-Zubaidy MH. Interaction of metoclopramidee with Choline- sterase inhibitors in chicks. M.Sc. Thesis, College of Veterinary Medicine, University of Mosul, Mosul, 2004. [unpublished]

38. Bruning JL, Kintaz BL. Computational Handbook of Statistics. Illinois: Scott, Foresman and Co., 1977: 18-9.

39. Petrie A. Lecture Notes on Medical Statistics. Oxford: Black Well Scientific Publications, 1978: 56-60.

40. Karanth S, Pope C. In vitro inhibition of blood cholinesterase activities from horse, cow and rate by tetrachlorvinphos. Int J Toxicol 2003; 22:429-33.

41. Mustafa FY, Mahmood AA, Qasem TE. Synthesis of new metoclopramide derivatives and in vitro evaluation of their human cholinesterases protection against Chlorpyrifos. Iraqi Journal of Pharmacy 2011; 11:58-69. 
